\title{
Interpersonal intelligence and prosocial behavior among elementary school students
}

\author{
Fitri Ayu Kusumaningrum ${ }^{a^{*}}$
}

\begin{tabular}{l}
${ }^{a}$ Department of Psychology, Faculty \\
\hline C H R O N I C L E \\
\hline Article history: \\
Received: April 18, 2019 \\
Received in revised format: April \\
282019 \\
Accepted: May 22, 2019 \\
Available online: \\
May 22, 2019 \\
\hline Keywords: \\
Interpersonal intelligence \\
Prosocial behavior \\
Elementary school students \\
School environment \\
Counseling teachers \\
\hline
\end{tabular}

A B S T R A C T
This research aims to analyze the relationship between interpersonal intelligence and prosocial be-
havior among students of elementary school. As a case study, it takes 156 students of an elementary
school in Yogyakarta Special Region, Indonesia as participants aged $10-12$ years old. The result
shows positive and significant correlation between interpersonal intelligence and prosocial behav-
ior among participants, as shown by coefficient of correlation $r=0.722$ and $p=0.000$. Three aspects
of interpersonal intelligence also show significant correlation with prosocial behavior. The finding
suggests the need of school endeavor to improve environment that enhance interpersonal intelli-
gence and prosocial behavior. Furthermore, the finding also suggests the importance of counseling
teachers to develop students' interpersonal relation skills to enhance their interpersonal intelligence.
As interpersonal intelligence was enhanced in school environment, prosocial behavior is expected
to be improved in students' daily life.

C 2019 by the authors; licensee Growing Science, Canada

\section{Introduction}

Many researchers believe that as children develop their physical abilities, some prosocial behaviors will also grow with them. Underwood and Moore (1982) for example conclude that altruism, as one of important aspects of prosocial behavior, has relationship with age. Furthermore, Davis-Kean et al. (2009) also suggest that level of prosocial behavior will increase along with age. On the other hand, interpersonal intelligence is one of intelligence forms possessed by children as an individual. This intelligence requires interaction with others to develop. It can be raised by increasing positive relationships, caring, cooperating and helping others (Campbell et al., 2004).

Prosocial behavior and interpersonal intelligence possessed by the children can be observed from their social interaction with others in their social environment. The social interaction that exists in children with high levels of interpersonal intelligence will further improve the quality and quantity of interaction between children and others. Furthermore, the experience of individuals' social interaction will affect the level of prosocial behavior (Rusbult \& Van Lange, 2003). When children interact with their families, for example, they feel safe, thus their social orientation to positive behaviors will also improve. Children

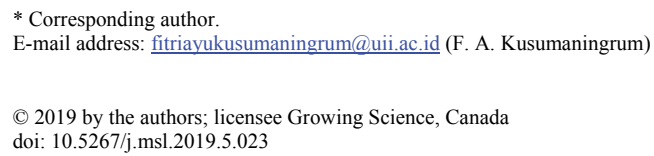


who get more expertise in social interaction, receive more knowledge about the world and better understand other people's emotions, their prosocial behaviors become more frequent and more effective (Berndt, 1985; Ongley \& Malti, 2014; Bagherpour \& Shamshiri, 2018).

During their time in elementary school, children enter stages of development where environmental influences have significant effect on their behaviors and even on their future. With this consideration, improving prosocial behavior in elementary school should be priority for school management as well as for parents. To develop prosocial behavior in elementary school, interpersonal intelligence will be important for children to ensure fruitful interactions with their peers. Thus, this research aims to analyze correlation between interpersonal intelligence and prosocial behavior among elementary school.

Some insights on how interpersonal intelligence and prosocial behavior are associated with each other have been discussed by many researchers. Hampson (1984) shows that people with high scores in prosocial behavior tend to succeed in their interpersonal relations. Furthermore, a good interpersonal relationship will improve prosocial behavior among elementary school students (Wentzel \& McNamara, 1999). In the same vein, Markiewicz et al. (2001) note that good relationship with peers will also increase prosocial behavior. Children are likely to develop high levels of prosocial behavior if they are raised in cultures characterized by parental and peer stress on consideration for others, sharing, and orientation to a group (Cialdini et al., 1982). Other research also indicates that interpersonal synchrony facilitates early prosocial behavior (Cirelli, 2018).

Indonesian researchers have also conducted many studies in association with interpersonal intelligence and prosocial behavior. Studies on interpersonal intelligence with students of different levels of education as participants show significant correlation with positive behavior. In elementary school, Aziz et al. (2012) show significant correlation between interpersonal intelligence and writing skill among students. Fadhillah et al. (2014) show that interpersonal intelligence has positive and significant correlation with adjustment to opposite sex among junior high school students. While Mareta et al. (2016) conclude that junior high school students with interpersonal intelligence can work and interact in learning group effectively. Other studies suggest that interpersonal competence and academic achievement have positive and significant correlation among senior high school students (Hinggardipta \& Ariati, 2015; Mursid \& Samio, 2012; Bahadoran \& Nazari, 2018).

Furthermore, studies on how to improve interpersonal intelligence have also been conducted in different levels of education. According to Muniroh (2009) social skills for elementary school students can be developed through character building, communication skill improvement through story-telling, role playing, sharing and networking. Rustiana (2013) suggests that physical education can significantly improve elementary students' emotional intelligence, including their interpersonal intelligence. For Irianti and Aningsih (2014), cooperative learning can significantly improve elementary students' interpersonal intelligence. For junior high school, Mareta et al. (2016) recommend Two Stay Two Stray (TSTS) method to help students with interpersonal intelligence to enhance their social skills. While for senior high school, group counseling (Utami, 2014) and Student Teams Achievement Divisions (Purnani et al., 2016) improve students interpersonal intelligence significantly.

Prosocial behavior also attracts many researchers to study its trend which according to Harefa and Indrawati (2014) tend to be higher for students of Islamic senior high school than their counterpart of general senior high school. Of factors affecting development of prosocial behavior, Susanti et al. (2013) suggest the importance of family and school environment role for preschool children. While Drupadi et al. (2014) mention children song lyrics has positive and significant effect on prosocial behavior of kindergarten kids.

Moreover, scout activities as an extracurricular according to Dewi and Saragih (2014) can improve prosocial behavior of junior high school students. While Zakaria (2016) suggests teachers to improve junior high school students' prosocial behavior by internalization of relevant matter in classes, outdoor activi- 
ties, and collaborating with other parties such counseling teachers. Other researchers also focus on creating model of learning for developing prosocial behavior for different levels of children development starting from early ages (Elyana et al., 2015) until high school (Primanda \& Pratiwi, 2016).

The present research considers previous studies as basis idea on the importance of interpersonal intelligence and prosocial behavior for child development. Thus, this research aims to analyze correlation of these two variables in the context of elementary education in Indonesia. This context as focus is based on limited notion of the topic from previous studies. The hypothesis of this research states is that there is a positive and significant correlation between interpersonal intelligence and prosocial behavior among elementary school students.

\section{Method}

\subsection{Participants}

The research was conducted in an elementary school in Yogyakarta Special Region, Indonesia. The school was chosen for being known for its inclusivity and differentiation in students' background. The participants were students in classes 4,5 and 6 of the school. Their ages during the research process were between 10-12 years old. In this range of ages, the children were in transition period from childhood to early adulthood. The way they think was more abstract, idealistic, and logical (Santrock, 2011, p. 16).

\subsection{Measures}

The research employed two variables: prosocial behavior and interpersonal intelligence. Prosocial behavior measurement was based on Prosocial Tendencies Measure (PTM) previously developed by Carlo and Randall (2002). This measure evaluates prosocial behaviors from 6 aspects: altruistic, compliant, emotional, dire, public, and anonymous. Interpersonal intelligence measurement was based on Anderson's theory developed further by Safaria (2005, p. 25). This measurement consists of three aspects of interpersonal intelligence: social sensitivity, social insight, and social communication.

\subsection{Data analysis}

Data analysis in this research consists several tests: reliability, normality, homogeneity, and correlation. Reliability of data was tested using Cronbach's Alpha in which only reliable data was included in analysis. The data was also tested for its normality using Kolmogorv-Smirnov normality test. Hypothesis of research whether a correlation between interpersonal intelligence and prosocial behavior existed or not was tested using Pearson's Product Moment. These tests were conducted using IBM SPSS Statistics 22.

\section{Results}

After being distributed and returned, final data show that 156 questionnaires were valid and reliable for further analysis. These questionnaires represented 156 participants who were students of classes 4, 5, and 6 in the school where the research was conducted. Of participants, 91 were male and 65 were female. Description of participants based on their age was depicted in Table 1 below. Of 71 participants were 11 years old, followed by 54 participants who were 10 years old and 31 participants who were 12 years old.

\section{Table 1}

Participants description based on age

\begin{tabular}{ccc}
\hline Age & $\mathrm{n}$ & Percentage \\
\hline 10 years old & 54 & $34.6 \%$ \\
11 years old & 71 & $45.5 \%$ \\
12 years old & 31 & $19.8 \%$ \\
\hline Total & 156 & $100 \%$ \\
\hline
\end{tabular}


Participants in this study were then classified into five diagnostic categories: very low, low, middle, high, and very high based on their score. These categories were based on empirical distribution of the maximum and minimum scores obtained from questionnaire. Table 2 below describes hypothetical and empirical scores for prosocial behavior and interpersonal intelligence. Maximum, minimum, mean and standard deviation of the scores were also included. Prosocial behavior scale in this study consisted of 33 thus minimum hypothetical score was $1 \times 33=33$ and maximum hypothetical score was $5 \times 33=$ 165. From the data obtained, standard deviation for empirical score was 16:36 and its mean was 119.76. Interpersonal intelligence scale consisted of 18 item with minimum hypothetical score was $1 \times 18=18$ and maximum hypothetical score was $5 \times 18=90$. Standard deviation for empirical score was 9:18 and mean for empirical score was 66.69 .

Table 2

Research data description

\begin{tabular}{lcccccccc}
\hline \multirow{2}{*}{ Variabel } & \multicolumn{4}{c}{ Hypothetical score } & \multicolumn{4}{c}{ Empirical score } \\
\cline { 2 - 11 } & $\mathrm{X}_{\max }$ & $\mathrm{X}_{\min }$ & Mean & $\mathrm{SD}$ & $\mathrm{X}_{\max }$ & $\mathrm{X}_{\min }$ & Mean & \multicolumn{1}{c}{$\mathrm{SD}$} \\
\hline Prosocial behavior & 165 & 33 & 99 & 22 & 153 & 73 & 119.76 & 16.36 \\
Interpersonal intelligence & 90 & 18 & 54 & 12 & 86 & 30 & 66.69 & 9.18 \\
\hline
\end{tabular}

Source: primary data

Based on the distribution of hypothetical and empirical scores of each variable, categorization of participants' score can be arranged. Table 3 below provides insights on how categorization of participants' score in prosocial behavior scale. Very low score was $<90.31$ and very high score was $>149.21$. The data show that 6 students or $3.85 \%$ had very low scores, 38 students or about $24.36 \%$ had low scores, 66 or $42.31 \%$ were in middle scores, 42 or $26.92 \%$ were in high category and only 4 or $2.56 \%$ were in very high category. Therefore, it can be concluded that participants' scores in general were in the middle category.

Table 3

Categorization of prosocial behavior score

\begin{tabular}{|c|c|c|c|}
\hline Category & Score range & $\mathrm{n}$ & Percentage \\
\hline Very low & $<90.31$ & 6 & $3.85 \%$ \\
\hline Low & $90.31-109.94$ & 38 & $24.36 \%$ \\
\hline Middle & $109.94-129.58$ & 66 & $42.31 \%$ \\
\hline High & $129.58-149.21$ & 42 & $26.92 \%$ \\
\hline Very high & $>149.21$ & 4 & $2.56 \%$ \\
\hline
\end{tabular}

Source: primary data

Table 4 below describes categorization of interpersonal intelligence score of participants. Very low score was $<16.52$ and very high score was $>83.21$. The results of the study have indicated in Table 4 and it appears that as many as 48 participants (about 30.77\%) had low score, $66(42.31 \%)$ were in the middle, 38 participants or $24.36 \%$ were in high category, and 4 or $2.56 \%$ were in very high score. It could be concluded that participants had middle score for interpersonal intelligence in general.

Table 4

Categorization of interpersonal intelligence score

\begin{tabular}{cccc}
\hline Category & Score range & $\mathrm{n}$ & Percentage \\
\hline Very low & $<16.52$ & 0 & $0 \%$ \\
Low & $16.52-61.18$ & 48 & $30.77 \%$ \\
Middle & $61.18-72.19$ & 66 & $42.31 \%$ \\
High & $72.19-83.21$ & 38 & $24.36 \%$ \\
Very high & $>83.21$ & 4 & $2.56 \%$ \\
\hline Total & & 156 & $100 \%$ \\
\hline
\end{tabular}

Source: primary data 
Normality test using one variable Kolmogorov-Smirnov test indicates K-S $Z=0.703 ; p=0.706$ ( $p>$ $0.05)$ for prosocial behavior and K-S $Z=0.671 ; p=0.759(p>0.05)$. These results show that interpersonal intelligence and prosocial behavior data had normal distribution. Furthermore, linearity analysis using compare means indicates $F=175.92$ and $p=0.00(p<0.05)$ which implies that interpersonal intelligence and prosocial behavior data were linear.

Correlation analysis between interpersonal intelligence and prosocial behavior using Pearson's Product Moment has shown a correlation coefficient $r=0722$ and $p=0.000$. It shows that there is a significant positive correlation between two variables, thus the hypothesis of positive correlation between interpersonal intelligence and prosocial behavior holds.

Homogenity test was also conducted resulting Levene $F$ Statistic $=0.027, p=0.869(p>0.05)$. This result indicates that the data was homogen so that gender difference analysis can be conducted. With equal variances assumed, data on prosocial behavior was analyzed for its difference in mean and resulted $t=$ 2.147, $p=0.165(p>0.05)$. Thus, data on prosocial behavior shows no differences between male and female participants.

\section{Discussion}

The results have indicated that interpersonal intelligence had positive significant correlation with prosocial behavior. Overall contribution of interpersonal intelligence to prosocial behavior was $52.2 \%$. This high contribution came from significant correlation of interpersonal intelligence's aspects with prosocial behavior. This result generally confirms previous finding (Wentzel \& McNamara, 1999) suggesting that acceptance by peer in early adolescent was related directly to prosocial behavior. Furthermore, other research also indicates that peers contribute to improve prosocial behavior of students (Wentzel et al., 2007). This research thus confirms the importance of interpersonal intelligence for students in school to improve positive behavior in their interaction with other students and teachers.

Participants of this research were 156 students of an elementary school in Yogyakarta with ages ranging between 10 to 12 years old and were in classes 4, 5, and 6. Most of them shows middle prosocial behavior score which was also found in other study of elementary students (Muniroh, 2009). The emergence of prosocial behavior in children may occur due to environmental factors (Knafo-Noam et al., 2015; Knafo \& Plomin, 2006). The school where this research was conducted had very conducive social environment to develop social interaction for students, so that prosocial behavior can be improved. Performing prosocial behaviors in the school environment always get positive reinforcement from teacher and friends. It was expected to increase a positive impact on creating prosocial behavior. Such effort in the school policy has strong background from previous research (Kato-Shimizu et al., 2013) that suggest social behavior tendency can be increased through more frequent interaction with peers. Teachers' reinforcement can also be viewed as potential effort to improve participants' prosocial behavior as previously suggested by many researchers (Kim et al., 2013; Racz et al., 2017; Rosenhan \& White, 1967; Wineburg, 1991).

Of interpersonal intelligence aspects, social sensitivity contributed $52.9 \%$ to prosocial behavior, with correlation $r=0.727$. The finding suggests that social sensitivity had high contribution to and significant positive correlation with prosocial behavior. Thus, making sure that students are well accepted in their social environment in school among other students is important. School administration and teachers should cooperate to improve friendly environment for student to observe and feel both verbally and nonverbally. This notion is crucial with consideration of potential bad effect of rejection by peers to antisocial behavior previously discussed by many studies (Dodge et al., 2003; Dodge \& Pettit, 2003; Menting et al., 2016; Parker \& Asher, 1987).

Social insight contributed $22.5 \%$ to prosocial behavior and its correlation $r=0.474$. This result suggests that social insight had low contribution to and insignificant positive correlation with prosocial behavior. Social insight will increase along with the process of social interaction of children in their social environment. Children will learn to understand the feelings of others, and this will further enhance the positive 
social interaction with other. This is in line with Rusbult and Van Lange's (2003) finding that individuals' experience of social interaction will affect prosocial behavior level. Thus, school administrator and teachers should enhance students' experience to socially interact in school.

Social communication contributed $58 \%$ to prosocial behavior with correlation $r=0.582$. This result suggests that social communication had high contribution and significant positive correlation with prosocial behavior. To socially communicate, students are required to have the mastery of communication skills in the process of interaction with others. Communication skills are important to develop some prosocial behavior such empathy as showed in many relevant studies (Harrison \& Hall, 2010; Jones et al., 2016; Redmond, 1985; Stiff et al., 1988). For teachers and school administrators, the finding in correlation between social communication and prosocial behavior should be translated in a more room for students' expression. Improving students' ability to express their thought in school will help them communicate in wider social environment and in the end improve positive behaviors.

Other finding of this research is that there is no difference between male and female participants in their prosocial behavior. It reflects that gender had no impact on prosocial behavior for this research. This result is intriguing because it contradicts with previous findings that emphasize important role of gender in prosocial behavior, with notion that female participants used to show higher score (Basti, 2007; Inglés et al., 2009; Muñoz Sánchez et al., 2004; Ongley \& Malti, 2014; Oscar \& Pohan, 2006). It can be assumed, based on this finding, that gender role might has not been developed by participants due to their ages. However, further research might be required to analyze this finding.

\section{Conclusion}

Previous results and discussions have shown that interpersonal intelligence and prosocial behavior among elementary school students based on this research had positive and significant correlation. Thus the hypothesis that there is a positive and significant correlation between interpersonal intelligence and prosocial behavior is confirmed. For the school manager, this result implies importance of conducive environment to develop students' interpersonal intelligence and prosocial behavior. Counseling teachers, who are directly involved in the process of student activities at school, can also play important role to guide students to practice interpersonal relationships that help them develop interpersonal intelligence.

This study has its unique contribution in discussion about interpersonal intelligence and prosocial behavior in the context of elementary school which at researcher's best knowledge is less explored. However, some limitations should also be discussed for improvement in next study. Main limitation is in the quality of scale used in questionnaire that should be developed in the future. Moreover, during the process of the questionnaire completion, participants were in the same classroom with teachers as part of school policy. Although researcher had previously announced that any result of questionnaire completion would be kept confidential, there was still a chance that participants completed the questionnaires with regard to their teachers presence. Objectivity issues might rise in this process.

Based on these limitations, next research in the topic should address quality of scale and questionnaire completion to ensure more solid background for data collection. Furthermore, direction of research can be addressed to consider other variables associated with prosocial behavior, such as the effect of media, conformity to peer, personality, religiosity and other factors that contribute to the formation of this variable.

\section{Acknowledgement}

The author would like to thank the anonymous referees for constructive comments on earlier version of this paper. 


\section{References}

Aziz, K., Joharman, \& Suryandari, K. C. (2012). Hubungan antara kecerdasan interpersonal, berpikir kreatif, dan hasil menulis siswa Kelas V SD Negeri di Kabupaten Kebumen [Correlation between interpersonal intelligence, creative thinking, and writing skill of elementary school students]. Kalam Cendekia PGSD Kebumen, 1(3), 1-8. Retrieved from http://jurnal.fkip.uns.ac.id/index.php/pgsdkebumen/article/view/605

Basti. (2007). Perilaku proposal Etnis Jawa dan Etnis Cina [Prosocial behavior between Javanese and Chinese ethnics]. Psikologika: Jurnal Pemikiran Dan Penelitian Psikologi, 12(23), 57-68. https://doi.org/10.20885/psikologika.vol12.iss23.art5

Bagherpour, M., \& Shamshiri, B. (2018). The effect of educational methods on creativity of pre-school children: A case study. Management Science Letters, 8(6), 717-724.

Bahadoran, H., \& Nazari, M. (2018). Investigating the effect of empowerment aspects on the competence level and success of primary school principals. Management Science Letters, 8(5), 445-454.

Berndt, T. J. (1985). Prosocial behavior between friends in middle childhood and early adolescence. The Journal of Early Adolescence, 5(3), 307-317. https://doi.org/10.1177/0272431685053005

Campbell, L., Campbell, B., \& Dickinson, D. (2004). Teaching and learning through multiple intelligences (3rd Ed.). London, UK: Pearson.

Carlo, G., \& Randall, B. A. (2002). The development of a measure of prosocial behaviors for late adolescent. Journal of Youth and Adolescence, 31(1), 31-44.

Cialdini, R. B., Kenrick, D. T., \& Baumann, D. J. (1982). Effects of mood on prosocial behavior in children and adults. In N. Eisenberg \& H. Beilin (Eds.), The Development of Prosocial Behavior (pp. 339-359). Elsevier. https://doi.org/10.1016/B978-0-12-234980-5.50018-3

Cirelli, L. K. (2018). How interpersonal synchrony facilitates early prosocial behavior. Current Opinion in Psychology, 20, 35-39. https://doi.org/10.1016/J.COPSYC.2017.08.009

Davis-Kean, P. E., Jager, J., \& Andrew Collins, W. (2009). The self in action: An emerging link between self-beliefs and behaviors in middle childhood. Child Development Perspectives, 3(3), 184-188. https://doi.org/10.1111/j.1750-8606.2009.00104.x

Dewi, N. K., \& Saragih, S. (2014). Pengaruh kegiatan ekstrakurikuler kepramukaan terhadap perilaku prososial remaja di SMP Santa Ursula Jakarta [Effect of scout on adolescent prosocial behavior in SMP Santa Ursula Jakarta]. Persona, 3(3), 253-268. Retrieved from http://jurnal.untagsby.ac.id/index.php/persona/article/view/415

Dodge, K. A., Lansford, J. E., Burks, V. S., Bates, J. E., Pettit, G. S., Fontaine, R., \& Price, J. M. (2003). Peer rejection and social information-processing factors in the development of aggressive behavior problems in children. Child Development, 74(2), 374-393.

Dodge, K. A., \& Pettit, G. S. (2003). A biopsychosocial model of the development of chronic conduct problems in adolescence. Developmental Psychology, 39(2), 349-71.

Drupadi, R., Palupi, W., \& Karsono. (2014). Pengaruh teks lagu anak-anak terhadap perilaku prososial anak TK [Effect of children song lyrics on kindergarten kids prosocial behavior]. Kumara Cendekia, 2(1), 1-8. Retrieved from http://jurnal.fkip.uns.ac.id/index.php/paud/article/view/4433

Elyana, R., Sofia, A., \& Risyak, B. (2015). Pengaruh penggunaan metode bermain peran makro terhadap perilaku prososial anak [Effect of macro role play method on children prosocial behavior]. Jurnal PGPAUD, 1(6), 1-8. Retrieved from http://jurnal.fkip.unila.ac.id/index.php/PAUD/article/view/11370

Fadhillah, J. F., Lilik, S., \& Karyanta, N. A. (2014). Hubungan antara body image dan kecerdasan interpersonal dengan penyesuaian diri terhadap lawan jenis pada siswa Kelas VIII Reguler SMP Negeri 9 Surakarta [Correlation between body image and interpersonal intelligence with adjustment to the opposite sex]. Jurnal Ilmiah Psikologi Candrajiwa, 3(2), 121-133. Retrieved from http://candrajiwa.psikologi.fk.uns.ac.id/index.php/candrajiwa/article/view/84

Hampson, R. B. (1984). Adolescent prosocial behavior: Peer-group and situational factors associated with helping. Journal of Personality and Social Psychology, 46(1), 153-162.

Harefa, K., \& Indrawati, E. S. (2014). Perbedaan perilaku prososial siswa Madrasah Aliyah (MA) berbasis pondok pesantren dan Sekolah Menengah Umum (SMU) [Prosocial behavior difference 
between students of Islamic senior high school and senior high school]. Empati, 3(3), 1-11. Retrieved from http://ejournal-s1.undip.ac.id/index.php/empati/article/view/7544

Harrison, M. A., \& Hall, A. E. (2010). Anthropomorphism, empathy, and perceived communicative ability vary with phylogenetic relatedness to humans. Journal of Social, Evolutionary, and Cultural Psychology, 4(1), 34-48.

Hinggardipta, R., \& Ariati, J. (2015). Hubungan antara kompetensi interpersonal dengan prestasi akademik pada siswa Kelas XI reguler di SMAN 2 Kota Tangerang Selatan [Correlation between interpersonal competence and academic achievement in students of sixth grade SMAN 2 Kota Tangerang Selatan]. Empati, 4(2), 8-13.

Inglés, C., Benavides, G., Redondo, J., García-Fernández, J. M., Ruiz-Esteban, C., Estévez, C., \& Huescar, E. (2009). Prosocial behaviour and academic achievement in Spanish students of compulsory secondary education. Anales de Psicología, 25(1), 93-101.

Irianti, D., \& Aningsih. (2014). Pengaruh model cooperative learning tipe jigsaw terhadap kecerdasan interpersonal siswa di Sekolah Dasar Negeri Kebalen 03 Bekasi [Effect of cooperative learning model of jigsaw type on interpersonal intelligence of students of SDN Kebalen 03 Bekasi]. Pedagogik (Jurnal Pendidikan Sekolah Dasar), 2(2), 9-19. Retrieved from http:/www.ejournalunisma.net/ojs/index.php/PEDAGOGIK/article/view/846

Jones, S. M., Bodie, G. D., \& Hughes, S. D. (2016). The impact of mindfulness on empathy, active listening, and perceived provisions of emotional support. Communication Research. https://doi.org/10.1177/0093650215626983

Kato-Shimizu, M., Onishi, K., Kanazawa, T., \& Hinobayashi, T. (2013). Preschool children's behavioral tendency toward social indirect reciprocity. PLOS ONE, 8(8), e70915.

Kim, J.-E., Doh, H.-S., Kim, M.-J., \& Kim, J.-H. (2013). The influences of parental attachment on social competence of school-aged children: The mediating role of empathy. Korean Journal of Child Studies, 34(3), 129-150.

Knafo-Noam, A., Uzefovsky, F., Israel, S., Davidov, M., \& Zahn-Waxler, C. (2015). The prosocial personality and its facets: Genetic and environmental architecture of mother-reported behavior of 7year-old twins. Frontiers in Psychology, 6, 112.

Knafo, A., \& Plomin, R. (2006). Parental discipline and affection and children's prosocial behavior: Genetic and environmental links. Journal of Personality and Social Psychology, 90(1), 147-164.

Mareta, F., Purnomo, E., \& Rizal, Y. (2016). TSTS dan Time Token untuk meningkatkan keterampilan sosial dengan memperhatikan kecerdasan sosial [Two Stay Two Stray and Time Token to improve social skill by considering social intelligence]. JEE (Jurnal Edukasi Ekobis), 4(6), 1-12. Retrieved from http://jurnal.fkip.unila.ac.id/index.php/JEE/article/view/11031

Markiewicz, D., Doyle, A. B., \& Brendgen, M. (2001). The quality of adolescents' friendships: Associations with mothers' interpersonal relationships, attachments to parents and friends, and prosocial behaviors. Journal of Adolescence, 24(4), 429-445.

Menting, B., Van Lier, P. A. C., Koot, H. M., Pardini, D., \& Loeber, R. (2016). Cognitive impulsivity and the development of delinquency from late childhood to early adulthood: Moderating effects of parenting behavior and peer relationships. Development and Psychopathology, 28(1), 167-183.

Muniroh, S. M. (2009). Pengembangan kecerdasan interpersonal anak [Improving child interpersonal intelligence]. Jurnal Penelitian, 6(1), 218-233. https://doi.org/10.28918/jupe.v6i1.218

Muñoz Sánchez, J. M., de Alba, M. del R. C., \& Lloret, P. B. (2004). An approach to the study of attitudes and strategies of social thought and their connection with disruptive behavior in the secondary school classroom. Anales de Psicología, 20(1), 81-91.

Mursid, R., \& Samio. (2012). Pengaruh strategi pembelajaran dan kecerdasan interpersonal terhadap hasil belajar Sosiologi siswa Kelas X SMA Negeri 8 Medan [Effect of teaching strategy and interpersonal intelligence to academic result of Sociology among students of Class X SMA Negeri. Jurnal Teknologi Pendidikan (JTP), 5(1), 87-100.

Ongley, S. F., \& Malti, T. (2014). The role of moral emotions in the development of children's sharing behavior. Developmental Psychology, 50(4), 1148-1159.

Oscar, P., D., \& Pohan, V. G. R. (2006). Perbedaan perilaku prososial berdasarkan orientasi peran jenis 
[Prosocial behavior differences based on type of orientation]. Psikologika: Jurnal Pemikiran Dan Penelitian Psikologi, 11(22), 129-36. https://doi.org/10.20885/psikologika.vol12.iss22.art5

Parker, J. G., \& Asher, S. R. (1987). Peer relations and later personal adjustment: are low-accepted children at risk? Psychological Bulletin, 102(3), 357-89.

Primanda, T. Y. W., \& Pratiwi, T. I. (2016). Pengembangan paket bimbingan perilaku prososial untuk Kelas VII [Developing of prosocial behavior textbook for seventh grade of junior high school]. Jurnal Mahasiswa Bimbingan Konseling, 6(1), 1-8.

Purnani, N. K. W., Imron, A., \& Arif, S. (2016). Pengaruh penggunaan model STAD (student team achievement divisions) terhadap kecerdasan interpersonal siswa [Effect of student team achievement divisions model on students' interpersonal intelligence]. Pesagi (Jurnal Pendidikan Dan Penelitian Sejarah), 4(3), 1-12. Retrieved from http://jurnal.fkip.unila.ac.id/index.php/PES/article/view/11313

Racz, S. J., Putnick, D. L., Suwalsky, J. T. D., Hendricks, C., \& Bornstein, M. H. (2017). Cognitive abilities, social adaptation, and externalizing behavior problems in childhood and adolescence: Specific cascade effects across development. Journal of Youth and Adolescence, 46(8), 1688-1701.

Redmond, M. V. (1985). The relationship between perceived communication competence and perceived empathy. Communication Monographs, 52(4), 377-382.

Rosenhan, D., \& White, G. M. (1967). Observation and rehearsal as determinants of prosocial behavior. Journal of Personality and Social Psychology, 5(4), 424-31.

Rusbult, C. E., \& Van Lange, P. A. M. (2003). Interdependence, interaction, and relationships. Annual Review of Psychology, 54(1), 351-375.

Rustiana, E. R. (2013). Upaya peningkatan kecerdasan emosi siswa sekolah dasar melalui pendidikan jasmani harmoni [Improving emotional intelligence of elementary students through harmonic physical education]. Jurnal Cakrawala Pendidikan, 32(1), 139-149.

Safaria, T. (2005). Interpersonal intelligence: Metode pengembangan kecerdasan interpersonal anak [Interpersonal intelligence: Method to develop child interpersonal intelligence]. Yogyakarta: Amara Books.

Santrock, J. W. (2011). Child development : An introduction (13th Ed.). New York, US: McGraw-Hill.

Stiff, J. B., Dillard, J. P., Somera, L., Kim, H., \& Sleight, C. (1988). Empathy, communication, and prosocial behavior. Communication Monographs, 55(2), 198-213.

Susanti, Siswati, \& Astuti, T. P. (2013). Perilaku prososial : Studi kasus pada anak prasekolah [Prosocial behavior: A study on preschool children]. Empati, 2(4), 1-8. Retrieved from http://ejournals1.undip.ac.id/index.php/empati/article/view/7433

Underwood, B., \& Moore, B. (1982). Perspective-taking and altruism. Psychological Bulletin, 91(1), $143-173$.

Utami, D. (2014). Pengaruh layanan bimbingan kelompok teknik permainan simulasi terhadap peningkatan kecerdasan interpersonal pada siswa [Effect of group counseling service on students interpersonal intelligence]. Jurnal Ilmiah Pendidikan Bimbingan Dan Konseling, 2(1), 50-55. Retrieved from http://e-journal.ikip-veteran.ac.id/index.php/kes/article/view/320

Wentzel, K. R., Filisetti, L., \& Looney, L. (2007). Adolescent prosocial behavior: The role of selfprocesses and contextual cues. Child Development, 78(3), 895-910. https://doi.org/10.2307/4620675

Wentzel, K. R., \& McNamara, C. C. (1999). Interpersonal relationships, emotional distress, and prosocial behavior in middle school. The Journal of Early Adolescence, 19(1), 114-125.

Wineburg, S. S. (1991). Factors affecting philanthropic behavior of Jewish adolescents. The Journal of Social Psychology, 131(3), 345-354. https://doi.org/10.1080/00224545.1991.9713861

Zakaria, A. F. (2016). Studi tentang upaya Guru IPS dalam mengembangkan perilaku prososial dan mengurangi perilaku bullying siswa di SMP [A study on teachers of Social Sciences effort to improve prosocial behavior and reduce bullying behavior of junior high schools students]. Jurnal Pendidikan Ilmu Sosial, 25(1), 117-124. Retrieved from http://ejournal.upi.edu/index.php/jpis/article/view/3675 
(C) 2019 by the authors; licensee Growing Science, Canada. This is an open access article distributed under the terms and conditions of the Creative Commons Attribution (CCBY) license (http://creativecommons.org/licenses/by/4.0/). 